\title{
Instructional Television: A Multimedia Approach for Effective Teaching and a Viable Solution to Poor Students' Academic Performace in Nigerian Schools
}

\author{
${ }^{1}$ Mustapha Mohammed, ${ }^{2}$ Haroun G. Haroun \\ ${ }^{1}$ senior lecturer NCE, B. Ed, M.sc Ed ( Edu Tech) Curriculum Department \\ ${ }^{2}$ Lecturer 1 NCE, B. Ed, M. Ed ( Edu Tech) Technical Education Department College of Education, P M B 44, \\ Azare. Bauchi State. Nigeria.
}

\begin{abstract}
The advent of Instructional Television for teaching and learning various programmed in the world is a field of immediate and increasing challenge to teachers. The term" Instructional television" refers to the use of Television medium in any of the various technical forms to present information ideas and experiences in any subject area and at any level of some portion of an organized educational programmed. Instructional Television as a multimedia approach can be applied in teaching various subjects in schools in order to stimulate student learning ability, interest and attitude in any given subject. A number of educational scholars have conducted researches on the use of Instructional Television for teaching and learning in many parts of the world and their findings reveal a significant increase in students' performances, attitude and interest with the use of Instructional Television. It is therefore imperative for teachers in Nigeria due to the ever increasing population of students in schools to start using this emerging instructional medium so as to achieve optimum student performances in various school subjects. This paper examined the usefulness of instructional Television in teaching and learning and its contribution to student's academic performance in schools. Finally, some useful recommendations were offered for consideration by Nigerian government.
\end{abstract}

\section{Introduction}

Instructional Television is an emerging instructional medium used in many parts of the world to improve students' academic performance and to enable a teacher teach a large group of students within and outside the school environment.

Instructional Television as described by James, Richard, and Fred(1969) constitute of simple television cameras used in classroom which serve as image magnifiers to aid demonstration, small portable video tape recorders which permit review and evaluation of student performance. In their own view Vankatali, Pannersalvam and Sauthanam (2004) describe Instructional television as programmed related to an organized programmed of formal instruction and is directed to individual viewers who come under non formal educational programmed where suitable follow- up work by the teacher is essential to consolidate the gain of knowledge.

Vankatali et al (2004) further stated that, instructional television programmed tend to bring into classroom experiences that local teachers cannot arrange. These include costly demonstration, complicated experiments and visual excursion to far off places and current events. Such programmed carefully produced an involving all kinds of inter related learning experiences which produce good result. They seek to overcome the obsolescence of the syllabus and present the latest advances in all fields. The programmed fully exploits the following potentials of the medium.

a. Immediacy for bringing to viewers the latest and existing new findings.

b. Omnipresence for taking the viewers to the exact place like a research laboratory of a hospital and conference.

c. Animation and special effects to help clarity concepts, invisible processes.

d. Visual power for showing a variety of things.

e. Intimacy with the things presented.

The term "instructional television" refers to the use of the television medium in any of its various technical forms to present information, ideas and experiences in any subject area and at any level as some portion of organized educational programmed. The methods and practices of educational television are rapidly evolving in the wake of changing educational philosophies and newly developing communication alternatives.

A study conducted by the ministry of education and culture in India (1981) recommended that television facilities should be used for educational development as well as notably for widening access to education, for reducing existing disparities between different regions of the country as well as different sections 
of the population and for bringing about an overall improvement in the quality of education. The study proved that television, through commonly devised programmed could contribute to the creation of national integration, bring about awareness of problems of national significance and develop desirable attitudes and values among children and youth and the population at large.

Various studies have shown that media have a profound influence on the minds of children as well as adults; some of them tend to encourage positive habits as well as curiosity on the part of the Historical studies revealed that there is no innovation investigated and discussed thoroughly as instructional television as it is the applications of television in formal course regardless of age or gender level and regardless of whether or not they are given for credit. This includes school instructions in part of courses for direct teaching or for facilitating lecture-demonstrations. Instructional television may be distributed by open or closed circuit systems or by both simultaneously.

The primary goal of Instructional Television is to improve quality of education and classroom utilization. Instructional Television now stands as the most significant cross road in its history.

A research study conducted by Wilbur Schramn (1962) revealed that there can no longer be any doubt that students learnt efficiently from instructional television. The fact has been demonstrated now in hundreds of schools, by thousands of students in every part of the United States and in several other countries. Another historical development of instructional television was the instructional television experiment (SITE) carried out in 1975 to 1976 in India which marked the most advanced and probably the largest experiment of human communication known so far. The main objective of the (SITE) was to experiment with satellite technology, providing instantaneous information for national development to those in the remotest part of the country and also provide for transmission to primary school children in these villages.

\section{Instructional Television and gain in knowledge}

Research studies on instructional television revealed that children exposed to instructional television programmed learned better than those that were not exposed to it. A study conducted by Neurath (1962-66) in India on evaluation of the school television in Delhi clearly indicate that children from schools taught with instructional television method performed better in question relating to visual perception and factual questions, while questions relating to understanding were left exposed to learners thereby improving their academic achievements in various subject exposed on the performance of both categories. Furthermore, he stated that students who were taught with instructional television method did distinctly better on the understanding (problem solving) of questions. Consequently, Neurath recommended instructional television to be used for teaching of physics and chemistry.

Some of his convincing remarks about his recommendations on the use of instructional television were:

(a) The whole teaching performance of every single teacher is slowly improving.

(b) Science teachers are becoming aware with new methods of teaching science and technical subjects. His observations about impact of instructional television on the students and school system were:

i. Television lessons provide a break in the routine, thus making school itself more interesting.

ii. The impacts of television lesson are less than the impact of television as an innovation within the whole television teaching process.

Rehman (1977) conducted a study about an assessment of the educational components of the satellite instructional television experiment (SITE, 1975 - 1976, India) based on the in-depth analysis of the responses of 2069 children and 785 teachers to eight programmed. The following major findings emerged out of the study. Comprehension in relation to the programmed was generally found to be partial. Some part of the concept was better understood some not so well and some not at all. The assessment made on the basis of responses to questions administered to test comprehension revealed a range of variation from 2 percent to 84 percent on individual questions among children and from 0.5 percent to 100 percent among teachers. The impact of the instructional television was assessed in terms of an overall comprehension of the programmed. The programmed were liked by the children from $80-93 \%$.

Aghi (1977) stated that, TV expose of science education programmed stimulated an interest among the experimental school children of grade III and V. They become "High" performers from "low" performance compared to control school children among whom the trend was "low" to "medium" and medium" to high" performance. Out of seven item tested, statistically significant information gain as a result of TV viewing of science education programmed was observed on items like "fuel" plant root system', milk," transportation" and "counting".

Another study conducted by space applications centre, Ahmedabad (1979) in Kheda India, a series of science programmed for children of 6 to 12 years was carried out. These programmed were on nutrition, hygiene, environmental science nature and the universe, etc. various questions were asked in order to know the impact of instructional television programmed the children of experimental villages gave appropriate answers, 
in responses to questions relating to principle of hygiene, simple experiments and information about surroundings as compared to control villages.

Kanade (1982) studied the impact of instructional television on the behaviour of the rural elementary school children drawn from television and non television schools. The major findings were as follows:

a) Creative behaviour of the children was found to be positively influenced as a result of exposure to instructional television verbal and non verbal aspects were influenced to some extent.

b) Curiosity behaviour was not affected. But inquisitive aspect of curiosity appeared to have been stimulated.

c) Children's language fluency was improved. But language refinement remained unaffected.

d) Children showed more positive attitude.

e) There was no evidence to suggest that intelligence together with television influenced criterion behaviour.

Coldevin (1974) in his research study on television effects on Canadian Arctic high school student: A cross - cultural comparison has shown some of the effects of television between students of different cultures. The purpose of the study was to contrast and compare television effects across three distinct types of students grouping serviced by the high school namely, Euro Canadian (white), Inuit (Eskimo) students in Frobisher Bang and Inuit (Eskimo) students from the various isolated settlements in the Eastern Arctic. The data was compared on the two primary levels of cultural racial origin Euro Canadian (white), Vs. Inuit (Eskimo) and made background. (Frobisher Bay) Vs settlements) specifically the independent variables were assessed in the following basis:-

\section{Television indices:}

a. Availability

b. Exposure levels and timing

c. Most at least preferred programmed

d. Perceived primary language

e. Projected situational utility role in terms of information education and community programmed

On the basis of findings of the present study, it can be concluded that fundamental attitudes have been appreciably altered among native students and that the changes were directly proportional to television exposes. The process of change will continue unchecked given the present programming format. It will seem therefore that of a familiarity with the traditional Eskimo life style value structure and language were to be forwarded to future generations critical changes were requisite in both the television format and formal educational curricular. In his own view Greenhill (1959) said that the students who had studied zoology by television lessons had obtained good results than their counterparts who were taught through conventional method. Further he observed through his experiment for a period of five years that the television instruction was effective.

In another study by Gardon (1960) in his experiment of language teaching through television has shown some difference between television teaching and face-to-face teaching by the regular teacher. The student performances were recorded through tape recorder before and after the remedial programmed. Student taught by television had an average gain score of 9.8 as compared with slight average loss of 0.4 for students taught by their own teachers.

Tsuji (1964) conducted a study on supplementary TV in an isolated village in Japan. Fifth grade study children in two schools received one science and one social studies programmed per week, twenty minutes in length. The other two schools in the village served as a control group. At the end of the TV classes in all the three measures namely intelligence social sciences and science were at 0.01 level of significance. There was no significant difference in social studies.

Maeda (1962) conducted an investigation with television lessons in a remote village school at, Doruba in Japan. After six month of viewing of a series of science lessons; achievement tests were given. It was observed that the ability of the pupils had been remarkably raised. After one year it was further investigated by the investigator of the ministry of education and notice that the ability in science had been higher than the national average's.

Kelly (1964) made more than three hundred comparisons on achievement tests between television teaching and conventional teaching during the period 1956-1961. These test comparison were classified under four subject matter areas: - English, Mathematics, science and social studies. Results of the comparison show that student generally did well when television was used as a regular resource. In one out of every four comparisons, significantly higher achievement scores were made by television groups.

Attitude, interest and acceptance of children towards instructional television in the world

A number of researches conducted across the world have revealed significant increased in interest and attitude among students towards instructional television in the world. Shukla and Kumar (1977) pointed out that 
children exposed to instructional television programmed did show more inquisitiveness particularly during classroom teaching related to general science while Aghi (1977) indicated that, TV viewing had an impact on the thinking of children.

In a research conducted in India by Agrawal (1981) revealed that there was general acceptance of use of television in the schools by teachers and students alike. This acceptance was reflected in the statements made by them after television was withdrawn the children felt miserable and lonesome and indicated that there food had become tasteless in the absence of television.

The influence of visual aid in shaping the children's attitude can be inferred from the studies conducted by Peterson and Thurstone (1933). In the early thirties they undertook to discover whether children social attitude could be influenced by movies. These investigations established conclusively that movies can change the attitude of children toward social issues. By measuring the cumulative effects of films, they found that attitude produced by film was lasting.

Meccoby (1963) reviewed studies on television and concluded that children attitudes and bodies can be shaped by what they see on television that emotions and impulses are aroused in the child view to match those portrayed by screw characters.

The collection of learning data on students attitude and aspirations of instructional television experiment of Mayo et'al (1975) in Elsalvador indicated that, majority of students responded favorably towards instructional television throughout the four years (1969-1972) in which attitudes were surveyed. However, high initial enthusiasm declined somewhat as students progressed from seventh to ninth grade. Attitude towards English benefited most from the introduction of instructional television a subject little liked by non instructional television students but, well regarded by instructional television students. Disadvantaged children and children with low general ability were more favorably dispose towards television series than their more advantaged peers.

Based on the above research findings made by various scholars in the world we can conclude that application of instructional television in Nigerian schools could be very useful in improving students' academic achievement. However, inadequate power supply and television facilities in every nook and corner in the country may hamper the progress of this type of instructional medium in Nigeria. However, political will and determination will enable the government to explore this emerging method of instruction in order to cater for the need for quality education in Nigeria.

\section{Conclusion}

It is apparently clear from the foregoing discussion that Instructional Television plays a vital role in improving academic performance of students whenever applied as a medium of instruction. Moreover, student attitude and interest towards a particular subject in school has remarkably improved when the device was used as a medium of instruction to students in many parts of the world such as Canada, Japan, India and China. Therefore, Nigeria being the most populous country in Africa and one of the largest economies in the continent should barrow a leaf from these emerging economies through the application of Instructional Television in order to improve students' performance in various categories of schools in the country.

\section{Recommendations}

$>$ Teaching in Nigerian schools is usually done through the conventional teaching methods such as lecture method, discussion method and demonstration method etc; all these methods do not invariably capture student interest and attention. Therefore, in order to fully maintain high academic standard in our schools, Instructional Television teaching strategies should be applied.

$>$ Instructional Television can be used over a wide range of locations in a given country; hence, the technique is suitable for a large country such as Nigeria.

$>$ Important mass literacy campaign concerning national issues such as epidemic out break like cholera, Ebola and meningitis etc could be disseminated all over the nation through satellite Instructional Television programmed, hence, the need for the device in our institutions and community centre's in Nigeria.

$>$ From the forgoing discussion in this paper application of Instructional Television greatly improved student academic achievement in schools, therefore, the need for implementing the technique in Nigeria in order to improve academic achievement of students.

\section{References:}

[1]. Aghi, B.M. (1977), Impact of science education programmed on SITE. Children of Rajastan, Ahmedabad, India: space application centre

[2]. Agrawal, B.C. (1981), SITE social evaluation: Results experiences and Implications. Ahmedabad, India: space application centre

[3]. Ahmedabad space application centre (1979), Science programmed for children Kheda ,India.

[4]. Coldevin, G.O. (1974), Television effects on Canadian Arctic high school Students': proceedings of the international conference on evaluation And research in educational television and radio. United Kingdom Open University: Pp $61-64$. 
[5]. Gorden, G.N. (1960), Educational television. Centre for Applied Research in education; New York.

[6]. GreenHill, L.P. (1959), Television in university science instruction, Pennsylvania state university, USA

[7]. James, W.B. Richard, B.L. \& Fred, F.H. (1969), Instruction media and Methods: New York: Mc Grow -Hill Book company

[8]. Kanade, H.M. (1982), A study on the impact of instructional television on behaviour of the rural school children. Unpublished PhD

[9]. Thesis, Baroda University Baroda: India, pp 250, 366.

[10]. Kelly, C.E. (1964), the efficiency of television in schools: unpublished PhD. Dissertation: India, pp, $24,244$.

[11]. Maeda, Y. (1962), Television for teaching. British association, a university Of Grenada lecture on Instructional television programmed: Canada.

[12]. Maccoby, E. (1963), the effects of television on children in W. Schramm (Ed): the science human communication. New York, pp $110-127$

[13]. Mayo, J.K. et al (1975), educational reform with Television.

[14]. The Elsalvador experience Stanford California: Stanford University press company.

[15]. Ministry of education and culture, India (1981), Satellite Instructional Television Experiment (SITE), India

[16]. Neurath, P. (1966), School television in Delhi. New Delhi: All India radio, India .

[17]. Rehman, S. (1977), A study in Educational television Department of education, ministry of education and social welfare, India.

[18]. Roy, B. (1974), a study of the cognitive effects of ETV programmed .Television Broadcast centre, India.

[19]. Schramm, W. (1962), what we know about learning from instructional Television in educational television. Institute of Communication Research, pp. 52-76.

[20]. Shukla, S \& Kumar, K. (1977), Impact of SITE on primary school children. Technical report, NCERT, New Delhi: India.

[21]. Tsuji, (1964), Supplementary television in an isolated village, a big media, Little media: tools and technologies for instruction, London: sage Publication Hills Company.

[22]. Peterson, R.C. \& Thurstone, L.L. (1933), motion pictures and the social Attitude to change, New York: Macmillan

[23]. Vankatali, Pannersalvam \& Sauthanam (2004), Educational technology for Schools and colleges, India: sterling publishers' plc. 